\title{
Present and Future Agricultural Extension System and International Agricultural Technology Cooperation of Sudan*
}

\author{
Sumaya Ahmed Hamid Geberaldar ${ }^{\mathrm{a}}$. \\ Duk-Byeong Park ${ }^{\mathrm{b} * *} \cdot$ Gyoung-Rae $\mathrm{Cho}^{\mathrm{c}}$ \\ ${ }^{a}$ Technology Transfer \& Extension Administration, Ministry of \\ Agriculture and Irrigation (Khartoum North, Sudan) \\ ${ }^{b}$ Department of Community Development, Kongju National University \\ (54 Daehak-ro, Yesan-gun, Chungnam, Republic of Korea) \\ ${ }^{c}$ Division of International Collaboration, Rural Development Administration \\ (300 Nongsengmeng-ro, Jeonju-si, Suwon, Jeonbuk, Republic of Korea)
}

\section{Abstract}

This paper explores agricultural extension systems, extension challenges, research and extension models, governance structures of agricultural extension and advisory services in Sudan. Agricultural extension services in Sudan are provided by a variety of governmental department and corporation. The Technology Transfer and Extension Administration under the Ministry of Agriculture and Irrigation, had been launched during mid 2000's aims at making

* Paper prepared to be presented at the International Symposium on the Systems and Development Strategies of Agricultural Extension of the World in November 2013, Jinju, South Korea.

** Corresponding Author(Duk-Byeong Park) email: parkdb84@kongju.ac.kr 54 Daehak-ro, Yesan-gun, Chungnam, Republic of Korea. 
Sumaya Ahmed Hamid Geberaldar • Duk-Byeong Park - Gyoung-Rae Cho / Present and Future Agricultural Extension System and International Agricultural Technology

extension systems farmer driven and farmer accountable by way of new institutional arrangements for technology dissemination in the form of community participation approach at the state level, to make the extension reforms have the active participation of farmers/farmer groups. The main problem facing agricultural extension services in developing countries is poor link between extension organization and research. Both extension administration and Agricultural Research Corporation (ARC) are operating as departments of ministry of Agricultural and irrigation for very long time. There are three recommendations to achieve the effectiveness of the Agricultural Research Corporations $(\mathrm{ARC})$ in reaching farmers. Firstly, extension staff members should be assigned to every ARC station. Secondly, the ARC might increase positions for Agricultural development specialist or Farming System Research (FSR) specialist. Their role would be to reflect the needed of farmer and translate them to the researchable topics. Thirdly, researcher should conduct more research on farmer's fields.

Key words: agricultural extension, agricultural technology cooperation, Sudan

\section{Introduction}

Sudan is an Afro-Arab country occupying remarkable strategic position in the center of Africa. The agricultural sector is the main production sector. An area of two hundred million Fedan(about four hundred million ha) is well ready for cultivation $(33.6 \%)$ of the Sudan total area, $25.8 \%$ forestry, $10.2 \%$ natural pastures, animal wealth more than 
140 million heads.

Agriculture is the main stay in the Sudanese economy as its contribute by $48 \%$ of the gross national product of employee $75 \%$ of the manpower in another view, the $65 \%$ of the population rely on agriculture. An annual share of $42.6 \%$ of the gross local production is coming from the agricultural sector followed by $25.8 \%$ from the industrial sector and $31.6 \%$ from the services sector

The federal ministry is entrusted for natural resource conservation, overseeing. The federal agricultural institution and rendering the basic agricultural services such as research, extension, plant protection, information processing, promotion for agricultural investment, supporting the external cooperation, quality control, and training at federal level.

Future success of rural development efforts in developing countries will depend not only on the presence of technical expertise and availability of resources but also on each government's willingness to redefine the role of its institutions and to allow the active participation of rural people in formulating and implementing rural development programmes (Swanson \& Samy, 2002). This paper explores agricultural extension systems, extension challenges, research and extension models, governance structures of agricultural extension and advisory services in Sudan. 
Sumaya Ahmed Hamid Geberaldar • Duk-Byeong Park - Gyoung-Rae Cho / Present and Future Agricultural Extension System and International Agricultural Technology

\section{Agricultural Extension in Sudan}

The extension services started in Sudan in 1958 supported by the American Agency for international development (USAID), which assisted the Ministry of Agriculture to establish an extension department, open extension units in some regions and train extension workers in America (Anas, 1991). From 1958 up to 1981, about 17 extension units were established in different parts of the country.

Currently, Agricultural extension services are provided by a variety of governmental department and corporation. The Agricultural extension and technology transfer Administration of Ministry of Agriculture and irrigation is the main governmental body responsible for providing a wider extension service. Other corporation offering extension are the Gezira scheme, Rahad scheme, New Halfa scheme, white Nile and Blue Nile pump scheme and rain fed mechanized farming corporation (Alamaen, 2009). Many other small and large none Governmental organizations (NGOs) offer extension services in sporadic and ephemeral farm (4600).

In 1958, the extension service was given the name Administration of Agricultural Extension and Education; later on 1975 Agricultural Education was transferred to the ministry of higher Education and scientific Research, while Extension remained under the Ministry of Agriculture. In 1991, to meet the federal governmental situation, the administrative structure 
of the Ministry of Agricultural made some changes both in function and name. The National Extension services name had been given in 1991 .

Technology Transfer and Extension Administration under The Ministry of Agriculture and irrigation, had been launched during mid 2000's aims at making extension systems farmer driven and farmer accountable by way of new institutional arrangements for technology dissemination in the form of community participation approach at the state level, to make the extension reforms have the active participation of farmers/ farmer groups.

The main activities include farmer-oriented activities (training, demonstrations, exposure visits, group mobilization and capacity building), information dissemination (exhibition, information technology, and print media), researched extension, and farmer's linkages as keys of reform are adequately addressed. However, this goes in line with one of the main objectives of Agricultural Revival Program which is the development of agricultural research, technological dissemination and adoption to sustain long- term productivity growth. It illustrates that this can be achieved through technologies such as improved seeds, cultural practices, water management techniques and rural lending. Therefore, increasing awareness of farmers can be attained by promoting a viable and effective agricultural extension programmers and bringing more land under cultivation. This provides Sudan with 
Sumaya Ahmed Hamid Geberaldar - Duk-Byeong Park - Gyoung-Rae Cho / Present and Future Agricultural Extension System and International Agricultural Technology Cooperation of Sudan

opportunities for growth and development but also poses new challenges. By use of appropriate tillage techniques and water management practices can shed positive changes.

Figure [1] The Organogram Of The Technology Transfer \& Extension Administration [TTEA]

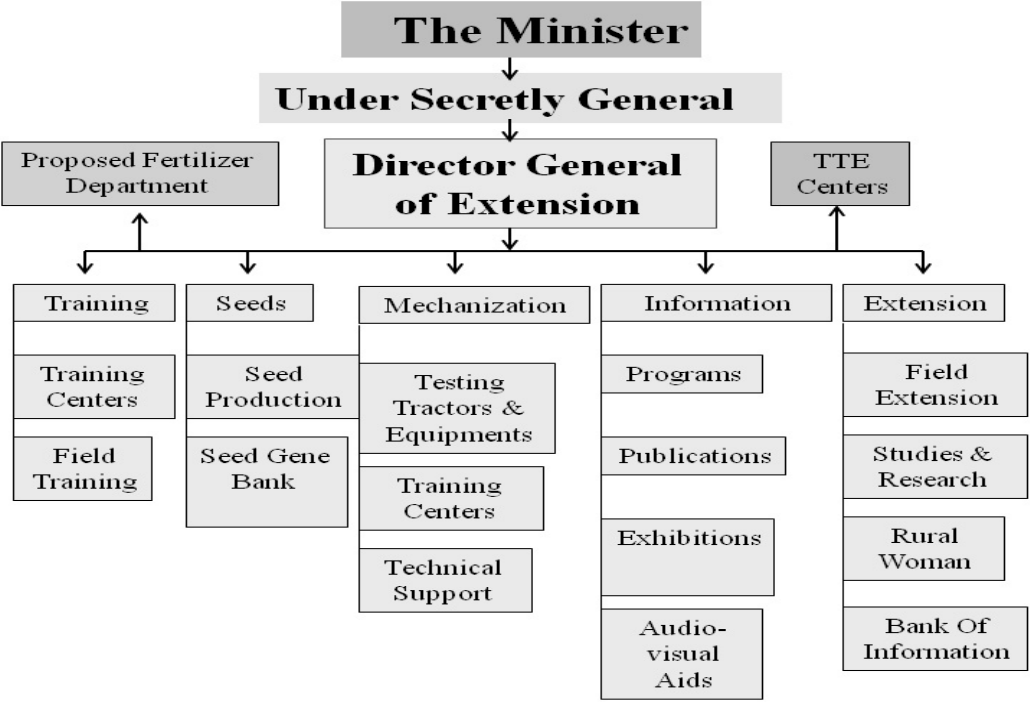

\section{Diagnosis of the Existing Situation in the Agricultural Sector}

A diagnosis of the current situation in the agricultural sector is using SWOT analysis. This approach explores the weaknesses and strengths in the performance of the sector, opportunities for development and the threats involved. 


\subsection{Strengths}

a. Vast agricultural lands suitable for cultivation.

b. Huge livestock resource potential and a sizable reservoir of fish resources.

c. Water resources from rainfall, rivers and underground aquifers sufficient to meet the requirements of the livestock population, fishery resources and rising of different crops and increasing the areas under forests and pasture.

d. Generations of trained manpower capable of leading the process of agricultural development.

e. A strategic geographical location which facilitates the marketing of agricultural and livestock commodities in the regional and international markets.

f. Commitment and a political will for equitable and sustainable socio-economic development.

g. The adoption of the federal system of government encouraged the participation of local communities in national development programmes.

h. Improvement of infrastructure such as roads, communication technologies, electricity, silos, quarantines and abattoirs helps promote free market mechanism and sends signals to producers to increase products coming to the markets and increase productivity.

i. The distribution of agricultural faculties all over the 
Sumaya Ahmed Hamid Geberaldar • Duk-Byeong Park $\cdot$ Gyoung-Rae Cho / Present and Future Agricultural Extension System and International Agricultural Technology

country will provide trained manpower in all areas of specialization required by the programme.

\subsection{Weaknesses (Opportunities for change)}

a. Low levels of productivity to all factors of production

b. Producers are trapped in traditional systems of production resulting in underdevelopment and weak technical, managerial and financial capacities of the producers.

c. The existing infrastructures are not commensurate with the requirements of the agricultural development.

d. Inadequacy of the procedures which control the quality of $\mathrm{AR}$ products and sanitary and phytosanitory measures which safeguard food safety.

e. Lack of strict measures to apply regional and international agreements on capacity building and enforcement of standards. This jeopardizes the competitiveness of Sudanese products in local and international markets.

f. Out-dated systems of production in the agricultural sector due to absence of a holistic vision of agricultural development.

g. The preparation of agricultural plans lacked the scientific and operational approaches. For instance, projections of production and exports lacked precision and were often exaggerated.

h. Lack of application of the recommendation research finding. 
i. Lack of coordination of policies between the various resources users.

j. Weak research and extension services and shortage of improved seeds.

k. Lack of capacity to produce agricultural inputs locally.

1. Weak linkages between stakeholders deprived local communities of the m. opportunity to participate in policy making and to reap the benefits of a balanced rural development.

m. Deep-rooted rivalries between professional and trade union organizations hampered the cooperation needed for optional use of agricultural resources.

\subsection{Opportunities}

a. The current economic stability, reflected in a single digit inflation rate and a stable exchange rate, provides a conducive climate for investment in the agricultural sector.

b. The increase in oil production and revenue provides an important source of financing rural infrastructure and agricultural inputs.

c. The production of oil and its by-products paves the way for the development of $\mathrm{d}$. agro-chemical industries in the country, namely fertilizer and insecticides industries.

e. The change towards an open economy creates a conducive 
Sumaya Ahmed Hamid Geberaldar • Duk-Byeong Park $\cdot$ Gyoung-Rae Cho / Present and Future Agricultural Extension System and International Agricultural Technology

environment for going into partnership with the international community, especially sister and friendly countries and investors in general. These partnerships will help in the transfer of technology, training and access to niche markets for high value and organic products.

f. Public awareness of the fact that agriculture is the main source of rapid and balanced growth has increased dramatically.

g. Utilization of the share of the Sudan in the Nile waters efficiently and effectively.

h. Application of water harvesting technologies on a large geographical scale.

i. Utilization of forward and backward linkages between agriculture and industry.

j. The strategic location of Sudan in Africa and the Arab World and its proximity to k. Europe makes it a potential centre for agricultural trade.

\subsection{Threats}

a. The policies, institutions and procedures which control financing are not suitable for financing agricultural producers, especially smallholders, nor is it appropriate for financing infrastructure.

b. Climatic changes resulting in fluctuations of production 
and productivity.

$85 \%$ of the animal resources depend on pastoral and transhumant systems of production, which render the provision of services and the transfer of technology needed for improvement difficult.

c. Trade barriers established by developed countries to protect their producers limit access to their markets.

d. The continuous deterioration of natural resources has a negative impact on the settlement of livestock producers and the development of the national herd. It is also associated with insecurity and tribal conflicts over resources.

The most important national, regional and international factors affecting agricultural development are firstly, the political stability and security induced economic stability resulting in a higher rate of growth, low inflation rate and the creation of an environment conducive to a balanced and sustainable development based on agriculture.

Secondly, the favorable geographical location of Sudan in Africa and the Arab World and its membership in the African, Arab and international organizations qualify it for an important role in regional food security

Thirdly, agriculture is the main sector for the Sudanese economy and the main source of income and livelihood for $70 \%$ of the population. 
Sumaya Ahmed Hamid Geberaldar - Duk-Byeong Park - Gyoung-Rae Cho / Present and Future Agricultural Extension System and International Agricultural Technology

Fourthly, the development of the agricultural sector ensures general peace, food security and settlement of people in the rural areas, and it is the easiest and most effective means for poverty reduction.

Fifthly, the phenomena of poverty, tribal conflicts and the claims of marginalization are evidences of the poor performance of the agricultural sector.

\section{Agricultural Extension System and Approaches in Sudan}

Agricultural extension is commonly identified with activity whereby agricultural extension worker interact with teaching farmer improved farming practices. New techniques and more productive and more efficient technologies or packages of technologies, are organized into and agricultural system which provide them with a constant supply of useful extension messages, technical and administrative supervision, and logical support.

In Sudan before the decentralization governance, Agricultural system was centrally directed and controlled, but under the federal role, Agricultural system was locally controlled (Eltayeb, 2005). This system has a rural development strategy. It is characterized by following certain kinds of approaches in 
their extension work. Because each system has an organizational structure, it has a leadership, resources of personal, equipments and facilities, a program with goal and objective as well as methods and techniques of implementation, also it has a linkages with other organization and different publics and its specialized grants.

The Agricultural extension system in Sudan is a delivery system type. It is deliver the information which the farmers need by using different and special methods and means according to the farmer's needs and farming requirement. The extension either has accessibility to it. The may be other inputs can be delivered, such as fertilizers, seeds and credit. This mostly occur in cases of development projects.

An approach is a style of action within a system. That embodies the philosophy, of the system. It sets the pace for all of the activates. It informs, stimulates and guides the different aspect of the system, such as its structure, its leadership, its programmed, its resources and its linkages. Agricultural extension services in Sudan adopted and use of different extension approaches to transfer technology packages to farmers.

\subsection{The Conventional Approach}

In early days of extension in 1958 the conventional approach was used in different parts of the country. The 
Sumaya Ahmed Hamid Geberaldar • Duk-Byeong Park $\cdot$ Gyoung-Rae Cho / Present and Future Agricultural Extension System and International Agricultural Technology

main objective of this approach is to increase production of food and export crops. It had direct impact on improving production of different crops especially in northern of central Sudan.

\subsection{Commodity Development Approach}

Irrigated cotton corporations in the Sudan, Gezira. Rahad, new Italia, Suki and white and Blue Bile Pump schemes adopted this approach mainly to increase production of the cotton crop. It was known as Inspectorate system.

\subsection{The FAO Fertilizer Program Approach}

It was introduced in Sudan to train and encourage farmer to adopt the use of chemical fertilizers.

\subsection{The Training and Visit Approach ( $T \& V)$}

The $T \& V$ system has been one of the most significant extension organizational developments in the last decades (van den Ban \& Hawkins, 1996). The approach was introduced in Sudan in 1985, which was sponsored by the world Band. The approach was introduced mainly in the Rahad and new Halfa schemes by injecting it to the inspectorate it to the inspectorate system. It was later introduced to different part 
of the country, including Blue Nile corporation, Khartoum state and Northen state. The important of $T \& V$ approach in the irrigated corporation Rahad and new Halfa has direct impact in improving formal linkage with research. The system tries to achieve changes in production technologies used by the majority of farmers through assistance from well trained extension agents who have close lnks with agricultural research. Also it has direct impact on increasing production of sorghum, groundnut cotton vegetable crops. It made a highly beneficial impact on agriculture in Rahad and motivated the farmers to adopt new crops, new varieties.

\subsection{Better Cultural Practices and Irrigation Management}

The technologies developed in the last decade by research, which shelved at research station are only now transferred to the farmers.

\subsection{The Integrated Agricultural Development Approach (IADA)}

This approach was introduced in Sudan in 1986 and was financed by German Agency for Technical cooperation (GTZ). It was introduced with the aim of improving vegetables and fruits production and promoting the concept of integrated pest management (IPM) among farmers. 
Sumaya Ahmed Hamid Geberaldar • Duk-Byeong Park • Gyoung-Rae Cho / Present and Future Agricultural Extension System and International Agricultural Technology

\subsection{The Integrated Rural Development Approach}

This approach was introduced of in the area of Jebel Marra from 1980 to 1995 financed by Arab Development fund (AAF) and European Economic Committee (EEC). It covered an area of $90000 \mathrm{~km} 2$ and population of 1.2 million. It was applied comprises 7 components mane by: Agricultural Extension and credit, adaptive research, community development, engineering, finance, administration and monitoring and evaluation.

\subsection{Farmer's Field School Approach (FFS)}

Sudan was the first country in Africa to apply this approach, which introduced in 1993. It was mainly adopted in the irrigated cotton schemes in Gezira and Rahad and in some regions of the Sinnar states. It goes beyond the objective of in increasing production to understanding the ecosystem and ecological environment for sustainable and breathy agricultural development. The approach has direct impact on change the attitude, behavior and skills of the farmers by using the integrated pest management (IPM) concept to reduce the effects of pest's damage.

The main problems and issues facing extension system are the issues of control, purpose, staffing, resources and cost, and accountability. 


\section{Government Extension Agents and Programs}

The extension agents have been widely distributed at both federal and state levels (17 states). Therefore those who are at the federal level are civil workers under the umbrella of the Federal Ministry of Agriculture and Irrigation. Their mandate is to develop, design and implement the national government policy, strategy, program and projects. They also act as technical pack up providers. Thirdly they are representatives of the official federal extension locally, regionally and internationally.

At the state level they are laying under the responsibility of the state's governments. Their administrative reporting and accountability belonged to their states, but technically to the federal directorate.

The Government Extension Program focus on increasing crop production and productivity, improving the cropping patterns and farming system, strengthening the institutional linkages, promoting the capacity building and capability recovery for human resources and extension cadres, developing and implementing the extension policy and strategy towards the market oriented production rather than the subsistence one, developing and implementing mutual partnership with other relevant institutions to enrich the development aspects, and 
Sumaya Ahmed Hamid Geberaldar - Duk-Byeong Park - Gyoung-Rae Cho / Present and Future Agricultural Extension System and International Agricultural Technology

maximum utilization of the IT technologies and extension publications as supporting program.

The common extension methods usually used in the Sudan are the farmer field school (FFS), demonstrations, cross-site "cluster" meetings, seminars and workshops, farm exchange visits, field days and sites touring, capacity building and technical assistants, and monitoring \& follow up (Anas, 1991).

\subsection{Transportation and communication tools of field agents}

The number of transportation means (vehicles and motorbikes) is inadequate. The total number of allocated vehicles for extension work at both federal and state level is not exceeding two or three for each of them. This considers the main factor which weakling the extension performance (Rahman, 2014).

Acquisition of computers and internet services and training is highly needed, because they can be available at capitals and $\mathrm{HQ}$ of states. The $\mathrm{HQ}$ at the state capitals and the units in the main town of each locality need to be supplied with computers and servers which would be linked through a WAN with $\mathrm{HQ}$ and with each other. The federal level is staffed with appropriate and trained persons. They are responsible of running the activities of the Information Technology Center of the Technology Transfer and Extension. They provide training facility to the extension stockholders when needed 
and requested.

An effective tool for information dissemination is internet and intranet through the Technology Transfer and Extension Administration website (www.ttea.sd.gov). The SMS mobile messages are very effective tool which used in a wide coverage of farmers and provide them with up-to-date information.

Recently the Technology Transfer and Extension Administration adopted a project of (Qaria net) (Village net) which aimed at making the extension whole stakeholders and services as a village through networking

\subsection{Linkages between research and extension in Sudan}

The main problem facing Agricultural extension services in developing countries is poor link between extension organization and research. This leads to weak movement of research results from researcher to extension and the feedback of information from extension to research. Due to this problem extension depends upon itself in giving information about Agricultural to farmers, which may be out of date or wrong.

Both extension administration and Agricultural Research Corporation (ARC) are operating as departments of ministry of Agricultural and irrigation for very long time. The level of linkage is very weak. There is no direct formal link between them. Always the dissemination of research finding to extension was done through annual reports, different committees and 
Sumaya Ahmed Hamid Geberaldar $\cdot$ Duk-Byeong Park $\cdot$ Gyoung-Rae Cho / Present and Future Agricultural Extension System and International Agricultural Technology

workshops.

The official channels of linkage between research and extension are not available functionally or structurally. It seems that whenever extension used scientific materials in dissemination its messages, this has been done through individual or personal initiatives. Linkage problems were enhanced because of the absence of proper persons within the research station to whom the extension agents and subject matter specialties (SMS) could refer.

Another reason is the administrative complication that usually accompany with the absents of delivery system of the research results after releasing automatically to the extension workers who own the foals means of disseminating them to the final users. In order to ensure Agricultural development in Sudan the government needs to invest heavily in each of the three categories, which represent the human resources in Agricultural namely, researcher, extension and the farmers. That is on top of the basic need for an intelligent intervention and government decision to reform the institution stricture of both extension and research organization to affect and consolidate farmers, extension- research linkage. This will ensure the maximum possible positive contribution of the three categories to Agricultural development.

There are three recommendations to achieve the effectiveness of the ARC in reaching farmers. Firstly, extension staff members should be assigned to every ARC station. Secondly, 
the ARC might increase positions for Agricultural development specialist or Farming System Research (FSR) specialist. Their role would be to reflect the needed of farmer and translate them to the researchable topics. Thirdly, researcher should conduct more research on farmer's fields.

The successful presences which established functional linkage through development project which were funded by international organization. In the mid 80's through the Agricultural research, Training and Extension project (ARTEP) introduced the T\&V system, in the Rahad and new Halfa schemes. In 1993 farmer's field schools through FAO project was introduced in the Gezira and Rahad. This linkage was created and made direct impact through the use of communication channels of group meeting in fields, on farm trials, field days an others.

\section{Suggestions on KAFACI's Agricultural Technology Cooperation}

The low productivity of crops is mainly due to poor Knowledge of producers about the new and improved technology which developed and indorsed by research institutions, reflect in low production compared with huge efforts, time and money allocated for the production which in most times 
Sumaya Ahmed Hamid Geberaldar • Duk-Byeong Park $\cdot$ Gyoung-Rae Cho / Present and Future Agricultural Extension System and International Agricultural Technology

obtained from banks to other credit bodies. It's time to impose more efforts in cooperation through development programme and partnership.

\subsection{Capacity Building}

Low efficiency of manpower is the most important factor contributing to the low agricultural productivity in the country, and it is a major challenge to agricultural revival. This problem is aggravated by the fact that agricultural institutions are deficient in technical and administrative capabilities. Therefore, the agricultural revival programme must focus on building individual and institutional capacities to achieve the following:

Qualitative change in the attitudes of the producers through training and rehabilitation takes into account the relevant successful experiences, and implementing policies which result in increasing producer income, and thereby encourage producers to stay in and improve their enterprises. This requires implementing the following strategies:

6.1.1. Making finance conditional on the use of improved technologies

Building the capacities of insurance companies assists in vertical and horizontal expansion. Availability of scientific and economic information helps to improve the productive 
and marketing efficiency of producers. Developing of the capacities of agricultural institutions as to be able to benefit from innovations in technology and management and lead the process of increasing production and productivity.

Updating existing legislation concerning agriculture, livestock and agro-processing and draft new ones aims at protection and sustainable management of natural resources and supportive of the key factors of success of the agricultural revival.

6.1.2. Rural development, food security and poverty alleviation Act

The law on subsidies and assistance supports livelihood in the agricultural sector.

Implement the procedures which aim at making use of the programmes initiated by WTO to help least developed countries benefit from the international trading system, especially access to international markets.

Complete institutional reforms of the irrigated agricultural parastatals taking into account the recommendations of the ministerial committees formed for this purpose and the experience of the Gezira Scheme. Implement the recommendation of the study on institutional reform of the semi-mechanized rain-fed sector. Review the organizational structures of the agricultural sector and related sectors to assist these sectors meet the challenges and requirements of the agricultural revival strategy. 
Sumaya Ahmed Hamid Geberaldar • Duk-Byeong Park - Gyoung-Rae Cho / Present and Future Agricultural Extension System and International Agricultural Technology

\subsection{Supporting Services}

The provision of supporting services, and the rehabilitation and development of the research systems and infrastructure, the training of scientists and building their capacities to cope with the rapid scientific developments at the local, regional and international levels, are key factors for agricultural development. To strengthen and upgrade these support services the following actions must be taken:

a. Introduce up-to-date equipment and technologies

b. Fill the shortages in trained scientists and ensure continuity and transfer of knowledge and experiences between generations in the scientific community.

c. Keep scientists abreast of new technologies

d. Enable research centers to prepare strategies for applied scientific research to serve the revival programme.

e. Link scientists working in government institutions with those working in educational and scientific research institutes.

f. Render the village the centre for dissemination of information and distribution of inputs, agricultural services, credit, training and extension through:

g. Implementation of research on farmers' fields

h. Strengthen the relationship between extensionists and agricultural researchers.

i. Train producers on the technological packages to improve 
agricultural and livestock production.

j. Adopt and use successful technologies to modernize farming systems and increase productivity.

$\mathrm{k}$. Conduct educational programmes for sustainable development.

1. Establish markets equipped with up-to-date technologies to ensure quality control, implementation of sanitary and phytosanitory and food safety measures.

m. Build capacities in the area of information and communication technologies with a view to supporting the decision making process and disseminating information to producers, scientists and politicians.

\subsection{Development and Modernization of Agricultural Systems}

Agricultural systems, including infrastructure, policies for resource management, technologies and husbandry practices remained stagnant for long and did not benefit from scientific breakthroughs in agricultural sciences. The revival programme seeks to make use of international technological innovations to improve and modernize these systems through:

Modernization of irrigation systems including the application of agricultural precision technologies.

a. Improvement of marketing and processing systems to increase the value added.

b. Adoption of agro-forestry systems for integrating crops and forestry production. 
Sumaya Ahmed Hamid Geberaldar • Duk-Byeong Park $\cdot$ Gyoung-Rae Cho / Present and Future Agricultural Extension System and International Agricultural Technology

c. Developing and scaling up of production under protected houses.

d. Developing tissue culture technology for multiplication of seeds and seedlings of such crops as dates, banana and potatoes.

\subsection{Agricultural Industrialization}

Agricultural industrialization adds value to agricultural commodities, increase revenues from agricultural enterprises and strengthens the forward and backward linkages between the agricultural and industrial sectors through the complementarily of production chains, specialization, product differentiation and quality control. To achieve a breakthrough in agricultural industrialization, the following actions must be taken:

a. Build the capacities of the agricultural sector through local processing and importation of basic agricultural inputs.

b. Improve the forward and backward linkages between the agricultural and industrial sectors with a special emphasis on agro-based and agricultural and livestock food industries which add the highest values to the gross domestic product, and on small scale rural industries.

c. Rehabilitate and modernize idle capacities in the agrobased industries with a view to achieving technical and 
economic efficiency. Special focus will be on food, weaving, textile, skin and hides and leather industries.

\subsection{Implementation of Quality and Food Safety Standards}

In spite of the increased awareness of the necessity to comply with food safety and quality standards and the implication of that for the flow of Sudanese products in regional and international markets, the food regulatory bodies are technically weak and inefficient.

The law for establishing and accreditation council is yet to be issued. This delays issuance of the certificates of compliance with food safety standards of locally produced and imported commodities, and jeopardizes customer welfare. To correct this situation, the following actions must be taken:

a. Expedite issuance of the accreditation law.

b. Link the focal point for the Codex Alementaruis in the Ministry of Agriculture and Forestry with the Agricultural Research Corporation and the Livestock Research Corporation.

c. Establish the National Council on Codex Alementaruis in the MSSO.

d. Adopt the system: "Hazard Analysis Critical Control Point (HACCP)" which ensures food safety at all points in the food chain from the stage of production to final intake by the consumer. 
Sumaya Ahmed Hamid Geberaldar • Duk-Byeong Park $\cdot$ Gyoung-Rae Cho / Present and Future Agricultural Extension System and International Agricultural Technology

e. Develop and enforce legislations on food safety and coordinate between the regulatory bodies implementing these legislations.

d. Develop national laboratories and build the capacities of the associated technical staff to be able to conduct the necessary analyses and be accredited internationally as reference laboratories.

\subsection{International Partnerships}

International partnerships are important instruments for implementing the projects and programmes of the agricultural revival. These partnerships are envisaged to realize all or part of the following objectives:

a. Provide or facilitate finance.

b. Enable the country to compete effectively in international markets.

c. Transfer new technologies and management systems.

d. Increase productivity and quantity and quality of production.

e. Increase efficiency and productivity of national producers

f. Realize self-sufficiency in strategic commodities on the basis of technical, economic and social feasibility.

To achieve successful and effective partnerships, the followings are considered prerequisite. Design a special 
programme under the leadership of the presidency to supervise the implementation of these partnerships including making contacts with the leaders of the targeted countries and chief executive officers of multi-national companies

\section{Conclusion}

The sustainable use of the huge and diverse agricultural resource potentials in the Sudan with a view to enhancing the welfare of its people has been a great hope and a moving target since the time of independence. These resources are envisaged, not only to meet the domestic requirements for food security, employment and foreign exchange earnings but also to enable the Sudan to offer significant contributions to regional and international trade and food security. However these expectations have yet to be fulfilled pending a real breakthrough to achieve a comprehensive agricultural development.

Taking the political, economic and social development of the Sudan into perspective, it is imperative that these resources be utilized earnestly to achieve a comprehensive agricultural development. Agriculture is the source of income and livelihood for the rural people, the engine of growth for the other economic sectors such as trade, industry and transport. The ultimate results of agricultural development would be the generation of job opportunities, rendering the 
Sumaya Ahmed Hamid Geberaldar • Duk-Byeong Park - Gyoung-Rae Cho / Present and Future Agricultural Extension System and International Agricultural Technology

rural areas more habitable, reducing poverty and striking a balanced distribution of the benefits of development between the different states and localities through giving more attention to the least developed ones.

The agricultural sector, leads to rural exodus to the urban sector. Taking these developments into consideration, the government undertakes urgent and serious actions to bail out the Sudanese economy from the distortions inflicted upon it by the current petroleum policy. These actions should aim to ascertain agriculture and industry as the leading sectors of the economy.

This strategy necessitates prompt actions designed to increase the efficiency of the agricultural sector and agricultureled industries with a view to enhancing the competitiveness of Sudanese commodities in local and international markets in preparation for accession to the World Trade Organization (WTO). 


\section{- REFERENCES}

Alamaen, E. E. E. M. 2009. The reality of execution of some agricultural extension policies: Case study Gezira state, Sudan. Thesis at University of Gezira. http://www.erails.net/images/sudan/ipmrt-center/elkhidir-elyass/file/ khidir\%20M_sc」Khidir\%20Msc.pdf

Anas, M. B. 1991. The guide of technician and agricultural extensionists, in the production of vegetables and fruits. University of Sudan.

Eltayeb, M. E. 2005. Agricultural extension in Sudan, policies and reality: The case of Khartoum State. Swedish University of Agricultural Sciences, Department of Rural Development and Agroecology. Master thesis.

http://citeseerx.ist.psu.edu/viewdoc/download;jsessionid=F4052CB3C6FA92268 3D32DA545477971?doi=10.1.1.119.6502\&rep=rep1\&type=pdf

Rahman, A. M. A. 2014. Use of information and communication technologies (ICTs) by agricultural extensionists in the Gezira state, Sudan. http://translate.google.co.kr/translate?hl=ko\&sl=en\&u=http://www.afaas-africa. org/media/uploads/documents/007_-_ict_extensionists.doc\&prev=search

Swanson, B. E. \& Samy, M. M. 2002. Decentralization of agricultural extension systems: Key elements for success. Paper presented at the Workshop on Extension and Rural Development: A congress of View on Institutional Approaches? November, 12-15, 2002, International Food Policy Research Institute in Washington DC.

Technology Transfer and Extension Administration. www.ttea.sd.gov.

Van den Ban, A. W. \& Hawkins, H. S. 1996. Agricultural extension. Cambridge: MA: Blackwell. 
Sumaya Ahmed Hamid Geberaldar - Duk-Byeong Park - Gyoung-Rae Cho / Present and Future Agricultural Extension System and International Agricultural Technology

\section{수단 농촌지도사업의 현재와 미래}

\section{수마야 하메드 하미드 게브라이다 ${ }^{\mathrm{a}}$ - 박덕병 ${ }^{\mathrm{b}} \cdot$ Gyoung-Rae Cho}

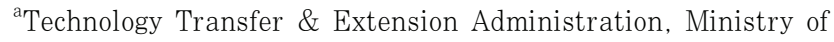
Agriculture and Irrigation(Khartoum North, Sudan)

${ }^{b}$ Department of Community Development, Kongju National University

(54 Daehak-ro, Yesan-gun, Chungnam, Republic of Korea)

\section{초록}

이 연구는 수단의 농촌지도사업의 시스템과 모델, 당면과제, 정부조직구조를 탐색하는 것을 목적으로 하고 있다. 수단의 농촌지도사업은 다양한 정부기구와 사업체에 의하여 수행되고 있다. 농업 및 관계부 산하의 농촌지도사업청은 2000 년에 새로운 시스템을 시작하였다. 이 시스템은 새로운 농민조직의 적극적인 참 여를 이끌어내기 위하여 제도적인 정비와 농촌지도사업을 추진하기 위하여 것이 다. 지도사업과 농업연구사업체 (ARC) 간의 연계는 오랫동안 수단의 농업 및 관계부 산하에서 이루어져 왔지만, 개발도상국이 직면한 가장 큰 문제는 연구와 지도간의 연계가 잘 이루어지지 않는 점이다. $\mathrm{AR}$ 의 효율성을 제고하기 위한 세 가지 방안은 다음과 같다. 첫째, 지도요원이 모든 $\mathrm{ARC}$ 에 배치되어야 한다. 둘 째, $\mathrm{ARC}$ 는 농업개발전문가 이거나 농업체계연구 전문가를 증가시켜야 한다. 이 들은 역할은 농민의 요구에 맞게 연구결과를 전달하는 것이다. 셋째, 연구자들은 현지농장에서 더 많은 연구를 수행해야 한다.

\section{주요어: 농촌지도, 농업기술협력, 수단}




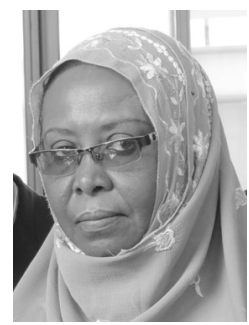

Sumaya Ahmed Hamid Geberaldar is a director of Technology Transfer and Extension Administration, Ministry of Agriculture and Irrigation, Sudan, Her research interests are rural development, food security, women empowerment and gender.

Address: Technology Transfer \& Extension Administration, Ministry of Agriculture and Irrigation, Khartoum North, Sudan.

e-mail) sumahamid@hotmail.com, phone) +249-919-606-530

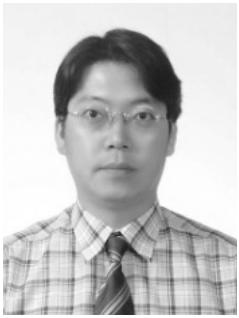

Dr. Duk-Byeong Park is an associate professor, Department of Community Development, College of Industrial Science, Kongju National University, South Korea. His research interests are rural development, agricultural extension, rural tourism.

Address: Department of Community Development, College of Industrial Science, Kongju National University, Yesan, Chungnam, 340-702, South Korea

e-mail) parkdb84@kongju.ac.kr, phone) 82-41-330-1383

Gyoung-Rae Cho is a researcher of the International Technology Cooperation Center, Rural Development Administration, South Korea. His research interests are rural development, agricultural extension and rural tourism. Address: International Technology Cooperation Center, Rural Development Administration, 300, Nonsengmeongro, Wansan-gu, Jeonju, Jeonbuk 441-707, South Korea. e-mail) cgyoung@korea.kr, phone) 82-63-238-1125 